\title{
Ethics in Classical Hindu Philosophy: Provinces of Consequence, Agency, and Value in the Bhagavad Gìtā and Other Epic and Śāstric Texts
}

\author{
Jessica Frazier $\mathbb{D}$
}

Faculty of Theology and Religion, Oxford University, Oxford OX1 4BH, UK; jessica.frazier@theology.ox.ac.uk

check for updates

Citation: Frazier, Jessica. 2021. Ethics in Classical Hindu Philosophy: Provinces of Consequence, Agency, and Value in the Bhagavad Gìtā and Other Epic and Śāstric Texts. Religions 12: 1029. https://doi.org/10.3390/ rel12111029

Academic Editors: Dafydd Mills Daniel and David

Peter Lawrence

Received: 23 August 2021

Accepted: 10 November 2021

Published: 22 November 2021

Publisher's Note: MDPI stays neutral with regard to jurisdictional claims in published maps and institutional affiliations.

\begin{abstract}
The idea of a univocal property of 'goodness' is not clearly found in classical Sanskrit sources; instead, a common ethical strategy was to clarify the ontological nature of the self or world in such a way that ethical implications naturally flow from the adjustment in our thinking. This article gives a synoptic reading of sources that treat features of ethics-dispositions, agents, causal systems of effect, and even values themselves-as emergent phenomena grounded in complex, shifting, porous configurations. One conclusion of this was that what 'goodness' entails varies according to the scope and context of our concern. Firstly, we examine how the Bhagavad Gìtā fashions a utilitarianism that assumes no universal intrinsically valuable goal or Good, but aims only to sustain the world as a prerequisite for choice. Recognising that this pushes problems of identifying the Good onto the individual; secondly, we look at accounts of malleable personhood in the Caraka Samhitā and Book 12 of the Mahābhārata. Finally, the aesthetic theory of the Nātya Śāstra hints at a context-constituted conception of value itself, reminding us that evaluative emotions are themselves complex, curate-able, and can expand beyond egoism to encompass interpersonal concerns. Together these sources show aspects of an ethical worldview for which each case is a nexus in a larger ethical fabric. Each tries to pry us away from our most personal concerns, so we can reach beyond the ego to do what is of value for a wider province of which we are a part.
\end{abstract}

Keywords: ethics; Indian philosophy; context ethics; consequentialism; emergence; Hinduism; Āyurveda; rasa theory; Mahābhārata; Bhagavad Gītā; Caraka Saṃhitā; Nātya Śāstra

Looking to the holding together of the world, you should act. (Bhagavad Gïtā 3.20). ${ }^{1}$

\section{Local Context, Creative Agency, and Emergent Values}

Often, when a philosopher might expect the classical culture of Hinduism (c.5th BCE5th CE) to speak of being 'good', it speaks instead of doing/being a particular thing well, and having understanding, self-control, and comprehensive grasp (jūāna, yoga, samgraha) as one does so. Why is this? Does Hinduism have no real ethics, only the social customs of dharma? Or is there some sense in which it sees over-arching comprehension, informed deliberation, controlled agency, and a discerning emotional sensitivity as key to what, in English, is called 'ethics'?

Where G.E. Moore's 'open question' method was designed to isolate a supposedly irreducible, universally intuitive sense in which the property of being good is 'ordinarily used' (Moore 1959, p. 6), classical Sanskritic Hinduism contains no obvious term that names such an intuition. Sources like the Upanișads, philosophical discourses in the Mahābhārata and Rāmāyaṇa epics, the śāstras' theoretical culture, and the late classical Purānas that shape much of modern Hinduism, all acknowledge at least four different 'arthas' or major goals of life. In addition, they enjoin a range of communally compassionate practices such as dāna (giving) and seva (service), and extol many stoic virtues of a pure (sattvic) attitude such as selfless charity, equanimity, and compassion. The literature as a whole deploys various terms that correlate partly, but only partly, with the English 'goodness' or Greek agathon, 
kalon, or arete. Such terms include auspiciousness (punya), well-being (hita), compassion (karuna), truthfulness or rightness (sat), or what is skilled (kuśala), pleasant (śubha), elevated (siddha), not wicked (apāpa), excellent (kalyāna) or good at doing/being something (su-). Thus, to Moore's 'What is good?' it seems that many Hindu religious and narrative texts might answer "Do you mean 'what is it best for there to be, or for us to do?' Well, that depends on the particular case and context..." While there are common abstract nouns for phenomena like truth (satya) or knowledge (jñ̄nna), classical Hindu discourses do not regularly use an acknowledged term for goodness or 'the Good' per se. Instead they unpack what is of value relative to different priorities, saying, as the deity Krishna does in the Bhagavad Gitta, 'This is how things are and how they will turn out: "reflect on this deeply, then do as you wish."'2 It is perhaps for this reason that Hinduism is often taken to favour a 'contextual' (Lipner 2019, p. 213), 'situational' (Sen 2014), 'context sensitive' (Ramanujan 1989, p. 47), or 'concrete cases'-based (Prasad 2008, p. 169) approach to ethics.

The Bhagavad Gitta, arguably classical Hinduism's most influential text, has generally been attributed some brand of consequentialism (e.g., Lipner 2019; Sreekumar 2012; Brodbeck 2004; Anderson 2012), or a 'categorical imperative'-like deontology (Malinar 2007, p. 20; Gaucchwal 1958). This interpretation is usually grounded in the notion of dharma - a natural and social order seen to ensure the corporate well-being of the world at large. However, the underlying metaphysics of moral agency and motivation that informed Brahminical philosophies of the time has rarely been addressed as the basis of a wider ethical worldview. As Clooney argues, attempts to measure Hindu approaches against mainstream Western ethical theories 'must proceed on a smaller scale, looking into the various Hindu traditions individually, to detect not only the content, but also the manner of ethical reasoning ... there is no end of the adjustments required to make "Hindu" and "ethics" work together (Clooney 2018, p. 300).

Bearing in mind this exhortation to build upward from the small scale, this paper draws on individual discourses from classical period texts (c. 300 BCE to 500 CE) of Sanskrit Brahminical literature. It focuses on the Mahābhārata's accounts of agency, and implicit accounts of motivation in early manuals of health and dramaturgy. Our priority is to construe an illuminating approach to ethics, whilst also hoping to clarify at least one way that early Brahminical India thought about these matters. Although from a text-critical perspective it would be simpler to focus on a single source, there is no single śästra or sūtra for ethics; we must turn to a 'large variety of texts in Sanskrit and other Indian languages setting forth various such proposals' (Perrett 2005, p. 323). Combining them emphasises their 'shared background of commonly agreed notions', a theoretical 'interlanguage', as Freschi puts it (Freschi 2015, p. 88), of causation, agency, composition and motivation. However, this should not imply that they share exactly the same beliefs, any more than a comparison of what Thales, Democritus, Aristotle and Plato had to say about change implies that they shared a single metaphysical interpretation of it. From a text-historical perspective, the Indian sources are diverse in authorship and period, ${ }^{3}$ but this selective synoptic reading aims to draw out 'immersed critical principles' (Ganeri 2005, p. 201) that were alive in the conversations of the time.

This article argues that an 'emergent holism' inflects the ontology of situation, agency, and subjective preference in these texts. Put briefly, it acknowledges that aspects of ethical phenomena (including situations, selves and preferences) are (a) complex conjunctions of multiple factors; (b) open to manipulation by sentient beings; and (c) generative of new phenomena when configured in certain ways. As with the ecology of the world and society as a whole (in the Bhagavad Gìt $\bar{a}$ ), living organic systems (in the Caraka Samhit $\bar{a}$ ), a kingdom (in Mahābhārata 12.308), or a narrative artwork (in the Nātya Śāstra), ethical situations are made up of conjoined contextual factors that have the power to reshape themselves when one or more sentient evaluative agencies are involved. As such, they entail assessing experiences and desires across subjects, and choosing outcomes-which is to say that take on an 'ethical' dimension. In each of these examples, there is no one ideal end-state; what is best depends on which province of the whole is under consideration. Much as the Buddhist 
philosopher Śāntideva built an argument for altruism by deconstructing the ontology of 'wholes' (See Williams 1998, pp. 107-19), so these texts apply their own ontology of emergent wholes in such a way that we see what a difference it makes to choose how we delineate the scope, beneficiary, and axiological value to which our actions are directed. Ethics here is the creative art of oversight-informed, self-aware, discriminating agency, enacted with regard not only to self but also to the wider context.

There was also a prominent discourse about the eternal core of the self (the ätman), and extensive soteriologies were built around the idea of disengaging from the world of cause, effect, emotion and embodiment. Concurrent discourses developed that were aimed at bringing the self to absolute freedom (Eliade 2009), independence (Potter 1991), solitude (kaivalya in Sāṃkhya), cessation (niroḍa in Yoga), or liberation into a "'perfected" and 'simple' state" (nihśreyasa for Vaiśeșika; (Moise 2019, p. 4)) that detached from worldly goals and interactions. These 'otherworldly' also thrived alongside the more 'worldly' philosophies of embodied agency that we will explore here, often interweaving with them. Indeed, techniques for control over the world's dependence relations could be used for different levels of freedom, from the discriminating self-direction of the discerning mind that we will look at below, to the 'absolute freedom' of the magician 'who had access to all experiences without being subject to their karmic effects' (Eliade 2009, p. 294), to the liberation of the person who had transcended this reality altogether and for whom 'goals' in the normal sense of potential, change, experience, gaining and becoming, are a thing of the past. Here we take the view that these approaches were not in competition. Rather, they related to worldly and beyond-worldly concerns so that the eternal ätman was just one of many aspects of the whole human person that each of us has the option to consider in our ethical decisions.

First we look to the Bhagavad Gìtā for the idea that we should support the order of the natural and social realms through 'world-maintenance' (lokasamgraha). This echoes other broadly consequentialist readings of the Bhagavad Gìt $\bar{a}$ that we will consider below, but it gives a different account of the consequences for which it aims: rather than aiming at a specific outcome - of communal good or personal equanimity for instance-it aims at the meta-ethical goal of ensuring the very possibility of choosing our values and actions. Secondly, this notion of context-specific right action is complemented by a model of contextspecific right agency. The accounts of personhood expounded in Mahābhärata 12.308 and the Caraka Samhitā emphasise that agents themselves are shaped by the world situations they are part of, so that 'the teleological view of actions as initiated and owned by individuals is, quite simply, a mistake' (Brodbeck 2004, p. 89). On this view, morally 'good' agency acknowledges its porous embeddedness in the situation, and directs its 'attention' (Ganeri 2017) intelligently, making adjustments that aid the telos of the whole of which it is a part. Thirdly, we consider whether such a contextual view might 'go all the way down' from actions, to agents, to values, by pointing to a context-specific conception of emotion found in Indian aesthetic theory. The theory of rasa sets out a special kind of evaluative affect that, as opposed to expressing the direct personal pain or pleasure of an individual, is an 'ownerless emotion' (Chakrabarti 2009; Boruah 2016) that responds instead to the complex impersonal arc of a narrative or scene. On each of the views set out here, ethical concerns emerge as a function of a given 'province' of concern. Religion's role here is not to produce commandments but to aid us in creatively comprehending our context and wielding our agency against a backdrop of the world's possibilities.

Before diving into three cases of this Indian approach, it is helpful to set the scene of classical Hinduism's sensitivity to context, as well as its fondness for understanding certain things as emerging from complex foundations. Among the canonical texts of classical India's Brahminical tradition, Dharma Śāstras treated social prescriptions, Mīmāmsāā ritualists theorised ritual participation, and the Sanskrit epics often speculated on right action; but there was no single Indian philosophical tradition dealing with ethics in the sense of asking what 'goodness' is. Instead we see genres concerned with specific areas of human concern such as social duty, political acumen, lovemaking and good lifestyle, health, 
arts. Alongside these fields of applied theory, we see a number of metaphysical debates about specific components that bear on ethics-knowledge (jñ̄nna) and discrimination (viveka), action (karma), etc. This leaning toward specificity may reflect the culture of the period: the millennium from $500 \mathrm{BCE}$ to $500 \mathrm{CE}$ in India was a time of growing empires. Cultivated intelligentsia sought patronage at the courts of regional kings, and in return they developed theories of language, logic, poetics, visual art, drama, medicine, astronomy, social organisation, lifestyle, political theory, and metaphysics. Across these genres, 'the social and the moral [formed] a unified sphere of knowledge', which helps to explain why 'the tradition has not thematized [moral philosophy] in any pronounced way' (Pollock 2016, p. 197). The epic literature of the Mahābhārata and Rāmāyana mirrored this complex world to itself and put its ideas into the voice of vivid characters deemed virtuous or wicked, but always complex.

These branches of knowledge shared certain cosmological assumptions: humans are agents within a powerful natural order, and innumerable deities exist, each with their own character, forming the centre of much worship and spiritual practice, but the divine is rarely, if ever, attributed any commandments. Even where, in sources influenced by the Vedānta tradition, they are portrayed as the personal 'face' of ultimate reality itself, they typically give not moral directions but information on the nature of the universe. One might say that Hindu deities invite a change of heart and mind, rather than moral demands. Meanwhile, Hindu religious goals were influenced by the presence of Buddhism, a radical philosophy that in some forms recommended the extinction of all self, action, and experience. This meant that Indian thinkers had to think hard about it is intrinsically good for human agency and experience to exist at all. This may have been important in shaping Hinduism's ability to affirm not just pleasure, but the full and variegated range of experiences. As Doniger put it, 'the ancient Indian knew well the Faustian lust for the full experience of the most diverse possibilities of human life; the Buddha saw this thirst as the cause of all human misery, but the Hindus did not dismiss it so easily' (Doniger 1973, p. 315). This is not to say that everyone in classical India felt a lust for life and was able to indulge it; rather, the collective imagination of the culture contained a teeming world of possible selves, paths and imagined life stories.

The result was a particularistic culture which affirmed that action can have value, but that value 'varies from place to place'; this view is 'sensitive to the geography of moral difference' and 'resists the application of categorical or universal laws' (Heim 2005, p. 343). Indian philosophical schools frequently acknowledge perspectival pluralism in epistemology. The Jain philosophy of 'viewpoints' or 'perspectives' (naya), ${ }^{4}$ the idea of cognitive 'projection' (or 'superimposition', adhyāsa) in the monism of Advaita Vedānta, and the holistic semantics of the great grammarian Bhartrhari all attest to a culture used to plural perspectives. Few general rules of behaviour were possible in a world of such diverse regions and cultures. Bimal Krishna Matilal interpreted the multiple recommendations of Hindu literature as a way of anchoring ethics to real conditions of life: 'the dharma-concept seems to underline links between ways of living, ways of seeing and ways of relating to life's ultimate issues. ${ }^{5}$ As an ethical concept, dharma is 'invariably contextual in connotation (in contrast to what might be a Kantian or absolutist reading of moral imperatives' (Lipner 2019, p. 213). As A.K. Ramanujan wrote of Manu, the imputed author of the most famous text on dharma,

To be moral ... is to particularise-to ask who did what, to whom, and when. Shaw's comment, 'Do not do unto others as you would have they should do unto you. Their tastes may not be the same' ... will be closer to Manu's view, except he would substitute 'natures or classes' for 'tastes' ... Hegel shrewdly noted this Indian slant: 'While we say, "Bravery is a virtue," the Hindoos say, on the contrary, "Bravery is a virtue of the Cshatriyas"' ... of, either the context-free or the context-sensitive kind of rules ... In cultures like India's, the context-sensitive kind of rule is the preferred formulation. (Ramanujan 1989, pp. 46-47) 
As we will see, this particularistic approach reaches deep into the different features that frame 'ethical' situations, for 'it is not only the conditions in which moral subjects act that are highly particularist and differentiated, but also human nature itself' (Heim 2005, p. 345).

In some cases, this ethical contextualism leant upon a corresponding implicit ontological contextualism. Some of India's theoretical discourses were concerned with the way that wholes with new capacities can emerge from quite different aggregated parts, and understood change in terms of variable configurations of those parts. This view could be applied to 'emergent' phenomena like ecological systems of nature and society, semantic meaning arising from words and sounds, biological life coming from organs and substances, consciousness arising from different mental faculties, or emotion generated from stories and events. ${ }^{6}$ Such phenomena could be shaped and controlled by adjusting their constituent elements. 'Combinationist' models of this kind were seen in the Vaiśeșika atomist school's 'mereological holism' (see Sinha 2016, p. 1 on the Padārthadharmasamgraha), the materialist school of the Cārvākas (Ganeri 2011, p. 674; Bhattacharya 2017, p. 350 on the elements doctrine of the Cārvāka Sūtras), passages in the early Upaniṣads (see Frazier 2017, pp. 47-50 on the ontological importance of arrangements or samdhā), the pharmaceutical 'combinatorics' of Âyurveda (Wujastyk 2000) that described the biochemical realm through aggregations (samghāta, a term also used in Jain philosophy), and some philosophies evoking the Sāmkhya school in the Mahābhārata (e.g., Malinar 2017b, p. 637 on 'samāhāra' aggregations). ${ }^{7}$ A similar conception applied to astrology, perfume-mixing, making necklaces and garlands, and the combination of syllables into new poetic metres or notes into music (Wujastyk 2000, pp. 486-88, 491). All were sciences that involved analysing the combination and conjunction of elements, using the resulting knowledge to actualise new possibilities. Buddhist texts were reluctant to acknowledge the ontological significance of the higher level phenomenon thus generated, but agreed that much is constituted in this way: Vasubandhu's (c. 5th century) 'weak emergence' (Hayashi 2016) described persons in terms of the emergence of a new unified phenomenon out of subsidiary constitutive configurations, while Buddhaghosa (5th century) explained the mind as an 'emergent dynamical system' (Ganeri 2017, p. 37), and Sāntarakṣita (eighth century) would later criticise 'brute emergence' in favour of a combination-specific emergence of consciousness (Coseru 2016, p. 372). ${ }^{8}$

This appreciation of the way that complex configurations can generate new phenomena furnishes a background to the three notions of good action, good agency, and good motivation that we explore below. We will see that world, self, feeling and preference all emerge from complex fabrics, and it is variation in the scale of our attention that lies at the heart of responsibility and altruism here. As Ganeri uses the term, the notion of 'attention' highlights the way that certain things are shaped by the orbit of influences that they take into account:

Our nature is to be active in the manner in which we orient ourselves in our environment, situate ourselves within it, search it, and scrutinize it. Attention is the name for this activity. Yet our environments are active too, calling our attention to features within them. (Ganeri 2017, p. 9)

In many ways, this critical rethinking of selfhood is a Hindu counterpart to the Buddhist doctrine of no-self, and the famous argument for altruism proposed by the early 8th century Buddhist Sāntideva. He held that when I realise my unified self is ontological plural and diffuse, then 'the care and concern I have for one other [my future self] ... must be universalized to all others, including contemporary others.' (Williams 2000, p. 425). That argument emphasises that a correct ontological realisation of the composite nature of the self should lead us to rethink our basic motivations - an idea with which these Hindu sources would agree. However, where the Buddhist arguments of thinkers like Sāntideva, for whom 'pain has to be seen as intrinsically bad' (Williams 1998, p. 165), take the negative value of suffering as an irreducible axiological core of ethics that is able to float above metaphysical questions, Hinduism does not assume any such universally-agreed intrinsic 
value. Below we explore the significance of this: it is not by overcoming the demands of the ego, but rather by expanding its scope of attention and feeling that the individual begins to act for all.

\section{Prerequisite Consequentialism: Lokasamgraha in the Bhagavad Gìt $\bar{a}$}

We first turn to a distinctive form of consequentialism aimed at securing the existence of the world and its ethical possibilities that is embedded in the Bhagavad Git $\bar{t}$ 's discourses on dharma. Some scholarship has interpreted dharma as a kind of Indian deontology advocating what should be the case, although this was grounded more in the natural order than some abstract conception of the 'good' (see Sreekumar 2012). More recently, the Bhagavad Gītā, has been interpreted as the influential locus of a utilitarian argument that advocates not the maximisation of happiness, but action aimed at 'the maintenance of cosmic order' (Malinar 2007, p. 87). ${ }^{9}$ One should act to support the conditions of life not because one assumes any particular general value that people aim for (e.g., well-being or freedom from pain), but only insofar as one affirms the possibility of any agency, choice, and experience at all. One can reject this activity only if one does not will the world, as the very field of ethical action, to exist. ${ }^{10}$ Indeed, this could be seen as the underlying goal of dharma-based principles generally; as Gupta puts it, "the dharma-imperatives in the Gìtā are hypothetical imperatives; they assume the conditional form, "If you wish to achieve $X$, then you should do Y," rather than the simple declaration, "you ought to do Y." "' (Gupta 2006, p. 382). ${ }^{11}$ The overall rationale of dharma, then, would take the form, "If you wish to achieve any $\mathrm{X}$, then you should do your prerequisite dharma." This foundational picture-which here we will call 'prerequisite consequentialism' - provides the groundwork for subsequent decisions about which particular values we want to pursue.

Historically, because its ancient Vedic origins, the Hindu tradition had a functionalist view of the cosmos as an order of complex interlocking systems. These included the elements, energy transfer and breath, the movements of the stars, potency of plants and biological substances, parts of the senses and reasoning, and different social functions-all captured in the analogy of a body's many parts. ${ }^{12}$ This order, initially called $r t a$ and later dharma, continually creates the dynamic reality that we know. One important feature of this idea of natural order was its conception of intrinsic predispositions. In the Mānava Dharma Śāstra, or 'Laws of Manu', the world's creation was depicted as establishing intrinsic characters in things, so that they repeatedly reinforce whatever is their local causal impact on the whole:

... In the beginning through the words of the Veda alone he fashioned for all of them specific names and activities, as also specific stations ... As they are brought forth again and again, each creature follows on its own the very activity assigned to it in the beginning by the Lord. Violence or non-violence, gentleness or cruelty, righteousness (dharma) or unrighteousness (adharma), truthfulness or untruthfulness-whichever he assigned to each at the time of creation, it stuck automatically to that creature. As at the change of seasons each season automatically adopts its own distinctive marks, so do embodied beings adopt their own distinctive acts. (Mānava Dharma Śāstra 1.21, 28-30; translation from (Olivelle 2004, p. 14)

'The world', on this model, is not a static object but a process, and once created it must continue to happen. This functionalist vision derived a normative character from the way that it underpins all life, pleasantness, suffering, beauty, horror, making it a 'thick' fact (see Gibbard 1992; Scanlon 2003). This meant that to act at all is to will either existence or destruction for all things. Thus in dharma, the "intermeshing of natural and normative is taken for granted" (Chatterjee 1986, p. 178). Humans' causal embedding in the systems of the functioning world gives life an 'artful' dimension, as Mahony put it (Mahony 1998). In this Vedic view, 'to be moral, to act rightly, is to realize actively one's place in the ritually constituted cosmos' (Monius 2005, p. 331). 
The idea that humans directly aid or impede the universe's ecology dates back to one of the earliest accounts of dharma in the Brhadäranyaka Upanișad (c.800 BCE). Here acts such as providing food and shelter to others, feeding livestock, offering shelter to wild animals, divine offerings, scriptural recitation, ancestor offerings, and procreation of offspring, are all lauded because they provide a world for all beings-including humans, animals, ancestors, seers and gods. Indeed, in feeding or sheltering beings, one 'becomes thereby a world for them', and 'as a man desires the well-being of his own world, so all beings desire the well-being of anyone who knows this' (BU 1.4.16). ${ }^{13}$

In chapter three of the Bhagavad Git $\bar{a}$, commitment to the functional order was expressed as 'holding together the world:' lokasamgraha. ${ }^{14}$ It recommends that all agents adopt cosmos-preserving action as a self-regulating rationale. Inaction means willing the world's destruction. The idea is not primarily that one would be punished for this, nor does the text even emphasise that this would be 'wrong.' Instead the overall consequentialist approach is simply to make our impact clear. The text speaks of the ongoing world processes in which we are implicated as the 'wheel' that is 'in motion'; it notes that we have the option to 'turn accordingly', 'unceasingly performing' works directed beyond personal events and goals, toward wider provinces that lie beyond the self. We can see this in the following passage:

So was the wheel set in motion: who does not turn accordingly, malicious, delighting in the senses, lives in vain ... Therefore, detached, perform unceasingly the action to be done, for the detached person who acts attains the highest. Only by action did [exemplars like good king] Janaka and the rest achieve perfection; so too, it is in looking to the maintenance of the world (lokasamgraha) that you should act. (Bhagavad Gītā 3.16-20) $)^{15}$

A tacit but important strategy in this section and the passages surrounding it is the emphasis on overcoming the demands of the senses (indriya; 2.58-68) and their objects (visaya, object or lit. 'province') which generate desiderative dispositions like desire, happiness, sadness, passion, fear and wrath (2.56). These form the sphere of what contemporary ethics calls the 'ego' in hedonist accounts, generally assuming that such concerns are our natural centre of gravity. However, in the classical Indian model of personhood the senses and the desirous passions of pleasure and suffering they induce are merely one province of our experiential environment. We also possess a natural ability to over-ride them, and this is an equally innate, defining feature of selfhood that leads to attitudes like interest in non-instrumental things (e.g., one's children, adjacent lives, distant crises, or the causally impotent worlds of arts and imagination). The text points out that we have this capacity for creative participation in larger purposes; this is, in a sense, its understanding of altruism.

Furnishing a vivid example of this attitude, the main speaker of the Bhagavad Gìt $\bar{a}$ (who is, of course, God) uses his own creation and sustenance of the world as an example. Krishna says, 'if I did not unwearyingly engage in action, then people everywhere would follow in my footsteps. These worlds would perish if I were not to perform these actions, and I would be a maker of confusion, I would destroy these beings' (3.23-24). ${ }^{16}$ The reader is meant to transpose this macro-model of agency onto his or her own local actions so that we enact action according to our place in the functional ecology of the cosmos, with the world's existence itself as our goal. ${ }^{17}$

We can see a complementary argument in Indian medical ethics where dharma is treated as the natural order that facilitates life. The Âyurvedic tradition is known primarily as an early medical science, but it also dealt with human flourishing broadly conceived, including mental states, the humours, and even the epistemology of diagnosis and the ethics of debate ${ }^{18}$ Indian medical saāstras shared 'a wider code of good conduct ... in the context of healthy and virtuous living for all' that has 'much in common with rules from brahmanic literature' (Wujastyk 2012b, p. 147). Like many śāstras, Āyurveda concerns life (āyuś) more than liberation, and its declared goal is to facilitate 'the good, bad, happy, and unhappy life. ${ }^{19}$ The Caraka Sam hitā describes the purpose of medicine as not merely 
physical health, but also the goods that lie beyond it: 'Disease-free condition is the best basis ( $m \bar{u} l a$, 'root, groundwork') of virtue, wealth, gratification and emancipation, while the diseases are destroyers of this [and of] well-being and life' (Sütrasthāna 1.16). ${ }^{20}$ As a precursor to opening the way toward these goals, the Caraka Samhitā treats the body as a foundation for all actions, qualities, and the higher forms of life and virtue. The account is reminiscent of lokasamgraha:

Here [in the person] are established action, [its] consequences, knowledge, delusion, happiness, suffering, life, death and ownership. He who knows this, knows destruction and creation, tradition, medicine, and whatever is to be known. There cannot be light, darkness, truth, falsehood, scripture, auspicious and inauspicious actions, if there is no active, aware person. There would be no substratum of happiness, misery, coming and going, speech, wisdom, sāstras, life and death, knowledge and liberation, if the person were not there. That is why the person is recognised as the cause by experts in causation. (Caraka Saṃita Śār 1.37-41) ${ }^{21}$

The priority of values is clear: 'out of all these desires one should follow the desire to live first. Why? Because when life breath is lost, all is lost' ${ }^{22}$ Even livelihood, the second value in the list of priorities is recommended in the next verse on the basis of its necessity for the basic infrastructure of life, not as the source of extraneous pleasures. An account of the dharma of doctors in an 11th century commentary by Cakrapāni emphasises that the appropriate task of the physician is to sustain the foundation of life as a necessary prerequisite to all else. Discussion of an applied case points out that one ought to be a vegetarian, but if a doctor's role is to compassionately preserve life, should he prescribe meat if it is needed to save life? Building on the statement that health is the root (which here seems to mean prerequisite ground) of all of the goals of life, Cakrapāni argued the following:

... health is the primary cause as far as the four goals of life are concerned. It is said that it is impossible for someone who has been caught by a disease to do anything at all about the aims of man ... The removal of health by diseases is one and the same thing as not achieving one's goals ... (trans. in Wujastyk 2004, p. 833)

The preservation of life itself functions here in a way that is structurally analogous to world-maintenance in the Bhagavad Git $\bar{a}$ : it is an instrumental good necessary for the further instrumental good of life in the world, which is itself a platform for the forming and fulfilling of all other goals-regardless of what each individual believes these to be. Our actions, then, are always components in a system generating the wider phenomena of what we call the 'world'. Understanding this, and knowingly using this power, is a foundational concern of Hindu ethics.

One might set out the arguments embedded here as a cluster of analyses from which ethical implications are taken to flow. It contains a causal analysis of the prerequisites needed for the world of living beings to function. This holds that the option of possessing life and action requires certain prerequisite platforms of life, and reasons that therefore those who wish for life and action to exist must also wish for those prerequisites. It complements this with a theory of action: our ongoing action in accord with certain systems is part of the causal network of factors that ongoingly sustain the world, and therefore, if we wish the world to exist, we must ongoingly act accordingly.

This is augmented with a strengthener emphasising the personally and pervasively binding implications of the theory. All of our acts, including inaction, influence the causal network of the world's prerequisite factors, and therefore there is no such thing as abstaining from consequences for the world. Further, this means that those who want any outcome for any aspect of the world need to act accordingly to achieve it; doing otherwise may/will directly impede that desired outcome. This takes on a particularistic cast by incorporating the notion that these sustaining systems are complex, and functionally interlocking. The world-sustaining causal network of which we are a part is not homogenous, but rather 
consists of localised subsystems that only have their effect when in the right conjunction. Therefore, we must act according to those systems, and to the overall conjunction of specific causes that are prerequisite to the world (e.g., here, according to dharma).

In the next section we will look at texts that add a theory of agency to this. It holds that agents are shifting and malleable phenomena that emerge from complex conjunctions that make up the world. Reason gives them the added ability to think, feel, and act on smaller or larger scales. Things like metaphysical reflection and the phenomenological adjustments of yoga alter this reasoning and the natural direction of their agency, and therefore egoism - the prioritisation of the most immediate personal concerns-is but one 'setting' of the self among others, and there is no reason to prefer it. This metaphysical rethinking of the self is taken to imply that the dependent, porous character of the self makes context responsibility a more appropriate way of acting.

\section{Curating the Ethical Self: Āyurvedic Samyoga and Epic Samgraha}

Provided that the world is functioning properly and allowing us to proceed with life within it, how should we form our goals and direct our actions? One difference between acting for the world in lokasamgraha, and acting for life in āyurveda, is the scope of concern (focusing on the world or the individual organism respectively). This hints that agency is scalable in multiple ways-(a) in terms of what we seek to benefit, for the Bhagavad Git à (e.g., one's own momentary preferences, one's immediate health, overall moral development, the well-being of one's family, the progress of one's society or of history itself, the balance of the natural environment, etc.); (b) in terms of the causal systems in which our action is embedded (e.g., a particular biological body, a pharmacological interaction, an immediate physical environment, the laws of karma, a specific community, etc.). The application of these multiple axes of influence shows that ethical acts are never as simple as the 'trolley problem' thought experiments might suggest (i.e., imagined scenarios where a person must decide between two morally significant outcomes). From the causal capacity one wields, to the scale of one's planned consequences, to the very disposition and deciding-power of the actor, agency is ontologically context-embedded, and variable in scope.

The final chapter of the Bhagavad Gĩta gives a fuller ontological account of agency. It uses the Sāmkhya idea of dispositional elements or gunas to explain that nature's own environmental dispositions flow through us and are expressed as our decisions. It then describes action as a whole as constituted not merely by the physical act but by its conjunctionthe term samgraha again — with prerequisite and efficient causes (the knowledge, known object(s), and knower as the factors that impel action) and with constitutive aspects (instruments, act, and agent as its constituents). ${ }^{23}$ In addition to the action itself, here and in chapter three it is reason that constructs freewilled action. When it possesses steadfast focus (dhrti) and is not focused on the self (anahamvād $\bar{\imath})$, it has the power to dislodge the insentient natural causation of the material world that we normally channel sufficiently for us to creatively intervene as we see fit (3.27-28). Thus the whole person as 'a complex and variable configuration that is united under the cohering governance of a 'core' will or agency' that is not just embodied but 'enworlded' in all it does (Frazier 2017, p. 40). This notion of 'harnessed' activity (yuktah samācaran; 3.26) can be traced back to a longstanding conception of ideal agency as a form of sovereignty-understood as complete grasp of all subsidiary instruments of the will, both those internal and external to the agent him or herself. Examples of this are found in the Chāndogya Upanișad's all-enabling, autonomybestowing virtue of self-governance (svarāj; 7.25.2) and the wider Upanișadic ideal of 'conquering the world' through purely epistemic means (see Frazier 2017, pp. 99-120), and it pervades the ideals of both good kingship and spiritual liberation in the Mahäbhārata (see Proferes 2007; Hegarty 2019, pp. 212-13). It is this agency that allows us to look beyond our immediate province of causation.

The Caraka Samhitā contains a similar account of selfhood but focuses on the way the deciding agent can constitute itself as well as the world. It depicts medical science as the manipulation of various aggregated factors that shape the body, mind and disposition and 
cause changes in them when they themselves alter. The self is described as a conjunction, literally 'linked together' (samyoga; SūS 1.42-44), into a 'tripod' of mind, body and self. ${ }^{24}$ These terms are familiar from the Vaiśeșika Atomist schools' description of the conjunction of body, senses, mind and self (see (Comba 2011) on the links between the Śārinasthāna and Vaiśeșika philosophy). ${ }^{25}$ The Caraka Saṃitā gives a kind of recipe for modifying the dispositions of the self. Through the application of substances that are similar (sāmānya) and differentiated (viśeșa), one can cultivate increase and merging or decrease and diversity of different characteristics in the body. ${ }^{26}$ The resulting body is a complex fabric: as Robertson (2017, p. 840) notes, it is continually shaped by both its constitution or 'internal ecology', and its harmonious conjunction (samāyoga) or accord (sātmya) with the external worldly context. The text uses the example of a string instrument, where the musical effect emerges from the right combination of physical parts and can be made to produce many different sounds (Caraka Saṃhitā Śar 1.34), ${ }^{27}$ or the materials that make a ceiling and help it stay up, or the parts that make up a chariot (3.14; see also 1.43-47). ${ }^{28}$ In all of these examples, bottom-up causation from some specific formation of creates something with new capacities:

The agent cannot proceed to action and knowledge in the absence of the senses.

The action which is dependent on certain entities does not exist without them, just as the potter is helpless to act, despite his knowledge, in the absence of clay (Caraka Samhitā Śar 3.19). ${ }^{29}$

An informed agent can also exert top-down causation to change itself. It can diminish its sense of ownership of the subsidiary elements, give up its executive function of control (1.142, 152-153), and thereby achieve liberation from worldly existence. Alternatively, it can extend its own 'concentrated knowledge everywhere' and study all the world's entities (3.20-21) in order to achieve a form of identity with the universe.

Seeing the entire universe in the self and vice versa gives rise to true knowledge. On seeing the entire universe in his self, one realises that the self is the agent of happiness and suffering and no other (5.7). ${ }^{30}$

Thus we have the capacity to contract and expand our attention, changing what outcomes to cultivate with our causal agency. The person, here, should be seen 'not as a body, but as a whole that is delimited by the spatial and temporal horizons of the world in which his phenomenal existence takes place' (Robertson 2017, p. 841). This mirrors Mahābhārata 3.202.13, sharing in a wider ethos of self-control and self-expansion, and adding an ecology of 'appropriateness to place' (deśa-sātmya; Robertson 2017, p. 856). The proper model for the person is not an object but a province on a landscape, and a shift of attention can help to construct a world-scale self rather than an excessively local one.

However, this Āyurvedic text has relatively little to say on what to do with one's agency. Its self-proclaimed task is one of facilitation, not moral direction. For a suggestion on this, we can turn back to the Mahäbhärata and a conversation in Book Twelve (12.308). ${ }^{31}$ In this tale within a tale, a female yogi named Sulabhā lectures an arrogant king on the realisation that many kinds of things—selves and sovereigns among them-are ontologically dependent on the changing context that forms their own identity. Its model of these features as continually emerging from complex, malleable subsidiary conjunctions is supported by a number of analogies: they are like fire emerging from the proper use of fire-making tools (12.308.125), sticks of wood conjoined to make a wheel or a stool (154-157), the movements of a horse combined into a process of running (123), the combination of words and interactions to make meaning and communication respectively $(86,91)$, kingship from the various parts of the state (153), and the emergence of biological life from the body's functioning parts (116-121). The account of this last example directly mirrors the approach to life as a product of combined functional systems that we saw in the Caraka Samhitā and even implied in the Mānava Dharma Śāstra and Bhagavad Gìtā, further emphasising the ongoing nature of the process: as the components of all people perform their particular functions but are discontinuous, their constitution is continually arising and changing. Thus, the text 
asks, who are they? Where do they come from? Where do they not come from? What is the connection between beings and the components that make them up? (121-125). ${ }^{32}$

The text uses this idea for two moral purposes: to deconstruct the king's overattachment to a rigid conception of what is right for each person by showing that selves are complex and changing, and to remind the sovereign that the essence of his own ethical duty as a king is to downplay his own ego, and cohere and guide the aggregated 'body' of the state that he governs (and in a sense is). ${ }^{33}$ Here the self is an assemblage (sāmagri $\bar{c}$ ) into distinct parts (prthak-kalā) that are combined (sambandha), producing a compounded aggregate (samghāta) of elements. ${ }^{34}$ The self is the part that 'governs' (rājya also meaning kingship) by exercising power or control (tantratā) even though we may not notice it because of its mercurial 'subtlety' (saukṣmyāt) like the changes in the flame of a lamp. ${ }^{35}$ However, this changeability alerts us to the fact that the self is constantly generated by the variable conjunction of components:

What connection is there between creatures and their bodies? From the contact of the sun and a jewel, or of two sticks, fire is generated; even so are creatures generated from the combination of the principles already named. ${ }^{36}$

The agent is really a province of interactions that generate the conscious self-awareness and localised rational control over the immediate causal environment that is foundational for discriminating action:

As lac, wood and dust are held together combined by drops of water, so are the existences of all beings, O King. Sound, touch, taste, form and scent, these and the five senses, each with their separate essences, exist in a state of combination like lac and wood. It is obvious that no-one asks of these "who are you?". Each also has no knowledge of itself or the others... Hear how they achieve these extra qualities; the eye, form, and light, constitute the three requisites of seeing, and it is the same for other forms of knowledge and objects. ${ }^{37}$

This last passage presses home the emergent character of subjective identity: no one constituent or mental function can be asked 'who are you?' It is only together that they form a self-aware identity. This conception is essential to the ethical moral Sulabhā tries to draw: there is no single ego, nor a single motivation or desire, nor is there really any discrete boundary between self and other/world. Evaluation and decision making operate in a much more free-floating way than egoistic accounts tend to acknowledge.

One of the most intriguing aspects of Sulabhā's teaching is that she also uses this ontological model to explain the emergence of excellence in any given function. One of these is successful meaning which emerges from the properly proportioned aggregation of words and persons (12.308.78-95). Good speech combines not only the language itself but also the perspectives of the speaker and audience so that a new causally potent phenomenon of communication results: 'When the speaker, hearer and discourse are all united together, $\mathrm{O}$ king, then the meaning shines out ... the speaker who speaks according to the goal of both his audience and himself is the true speaker, and no other, $\mathrm{O}$ king ${ }^{\prime}{ }^{38}$ She gives a similar account of corporate guidance in her culminating discussion of the dependent nature of kingship:

A king is always dependent on others whilst he engages in trivial matters; how can there be any independence for a king who is absorbed in the business of peace and war?...When he gives commands to others he is said to be independent, but when the command is carried out he then becomes subject to various factors. ${ }^{39}$

As elsewhere in the Mahābhārata and its Upanișadic sources, sovereign knowledge (rājavidyā; see Hegarty 2019, p. 213) is used here as an exemplar of executive agency, but this text emphasises the way it inevitably functions according to a complex ecology of factors. The analogies of a wheel and a stool, used to illustrate mutual interdependence, illustrate that guidance depends on its parts and (when sentient decision making is involved) should take them into account. Thus she tells the arrogant king this: 
"This is mine" you think, with regard to this city and this territory; whose are these power, wealth and these ministers of state, to whom do they not belong, $\mathrm{O}$ king? And is there anyone to whom they do not belong? An ally, a minister, a city, territory, punishment, treasury and monarch combine into a seven-spoked wheel: this is what is referred to as sovereignty, $\mathrm{O}$ king. Which of these seven parts could have a higher quality when, like three sticks standing together, each of them exists in a state of close dependence on the others? Each part in its time will dominate: whichever achieves its proper function attains precedence at that particular time. ${ }^{40}$

There is an irony to all of this: King Janaka had claimed in 12.308 .45 that a good king is like a good yogi because he is fully independent of his subsidiary dependents. Sulabhā reverses this claim: the good yogi is like a good king in that he comprehends, acknowledges, and fully channels his environmental context. He accepts that his very nature as the agent of sovereign control consists of the 'sovereign grasp' (räjyaparigraha; 12.308.51) of good governance over them all. This analogy of a king deconstructing his personal boundaries and dissolving into his realm is also found in a later Mahābhārata discourse (Anugitta 14.32). Here, King Janaka willingly accepts that he is the boundless provinces to which his agency is related:

I do not perceive any "area" [that is] the realm, though I examine the land carefully. When I did not perceive one in the land, I searched the capital city Mithila; when I did not perceive one in it, I searched among my subjects; when I did not perceive one among them, then I was perplexed. But then the perplexity passed, and my Intellect (mati) was present to me once again. By it I judge (manye) that I have no realm, that my realm is every place. Not even this body belongs to me-instead the whole earth is mine. ${ }^{41}$

This expands considerably on the older philosophical ideal of sovereign agency. The accomplished ethical agent in this passage has learned the lesson that egos are not fixed phenomena and can displace his own hedonism, knowing that he is not the 'small self' that he thought. He has the option to expand the scope of his action to encompass a wider context, reflecting, desiring, and acting as a 'large self'.

We can note here that the conception of what is ethical is that which acts responsibly for its context, and the philosophical strategy for encouraging ethical behaviour (i.e., action that transcends egoism and embraces a kind of altruism) is less to give an 'argument' for what we ought to do than to redefine the features of agency and action. Once this is done, all things being equal, we should naturally reason toward a new identity, comprehension, and motivation. This way of eliciting an ethical push from redefining the metaphysics of the self is familiar from Śantideva's famous Buddhist argument from the non-ultimacy of personal identity to altruistic concern for the suffering of others (of which more below). It is an approach that functions by re-informing the metaphysical model that inevitably frames our reasoning so that our decision making is naturally directed in a new direction.

\section{Ethical Provinces and Emergent Values: Rasa in the Nātya Śāstra}

It remains to ask what conception of motivations and values lies at the heart of this picture? Does moral value itself — that which we consider intrinsically good or bad-float free from this complex metaphysical fabric of self and world, or are they too woven into, and dependent on, their context; and if so, what would it look like to extend this bottom-up metaphysics into a bottom-up ethics? These questions reflect the underlying philosophical problem of whether any kind of ethical axis could emerge from a complex, bottom-up, built ontology, rather than be imposed on it based on some external authority. Might some ingredient of the conjoined situation be an active agent for the emergence of ethical value, generating some recognizable sense of generalised moral motivation?

While there is not scope in the present article to explore the Indian sources thoroughly, by way of an epilogue this last section looks at a passage that seems to apply a similar 
ontological conception to evaluative emotions. It looks at those emotions that are the emergent aspect of complex structured causal fabrics ('situations') that have feeling sentient beings as part of their composition. Emotions can be seen as the part of situations that attributes value to both the present and possible circumstances, thus generating the field of ethical significance for an individual or, when generalized, for a group. However, here too, the sense in which something is 'good' depends upon the constitutive context: what subjects are in play in a given case, and with which emotions, in what relationships, with what possible trajectories? Values for each situation are determined by the total configuration of emotions and hopes embedded in it.

For this, we draw on the Nātya Śāstra or 'Dramaturgical Manual' of Bharata (c. 500 BCE-500 CE); it contains India's earliest explicit theory of emotion and art, and it makes use of the familiar ontology of conjunction, complexity, malleability, and emergence. Its account sees certain emotional attitudes as states that arise from specific triangulation of ingredients that make up a situation, such as transitory affective responses (one's own or others'), relationships, and settings. The majority of the text is ostensibly aimed at teaching actors and playwrights how to manipulate the mechanisms of narrative and thereby stimulate the human heart-much as Âyurveda taught doctors to manipulate the body and stimulate its vital forces. ${ }^{42}$ However, the sixth and seventh chapters theorise a higher order kind of emotion involved in aesthetic experiences, called rasa. It is 'the subjective inner experience of relishing a work of (dramatic, literary, musical, or visual) art ... not an ordinary raw feeling but some sort of a transformed, 'cooked', meta-feeling, insofar as it is a kind of feeling at all' (Chakrabarti 2009, p. 190). At the risk of simplifying a complex tradition, rasa arises when the ingredients of narrative (such as settings, characters, and their relationships and feelings) combine into a sustained affective arc, an overall mood. This overarching feeling is considered the 'juice' or 'essence' (the literal meaning of rasa) of the whole artwork, distilling its constitutive 'conjunction of setting, physical sign and subsidiary feeling ${ }^{43}$ into an overall emotional 'flavour' that pertains to the whole state of affairs.

In describing the ontology of emotion, this śāstra uses a similar vocabulary of combination and emergence to that which Sulabhā and the Caraka Samhitā used to describe the generation of the self. The different elements are conjoined (samyoga) so that they

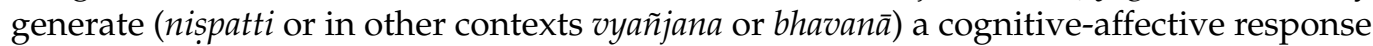
of a particular kind. To express this process, the Nātya Śāstra says that the generation of aesthetic emotion is like ingredients blended into a flavourful drink that, as with all skilful mixtures, has a new taste all its own:

Rasa (aesthetic emotion) arises from the conjunction of factors, reactions and transitory emotions. What would be an analogy? Just as taste arises from the conjunction of various condiments, spices, and substances, so rasa arises from the presentation of various factors and emotions. That is to say, just as physical tastes, that of lassi, for instance, or other such drink, are produced by substances such as brown sugar plus condiments and spices, so the stable emotion, in the presence of the various factors and emotions, turns into rasa. ${ }^{44}$

The analogy echoes the Cārvāka materialist school's image of ingredients being combined to create an intoxicant. ${ }^{45}$ Here we see the familiar ontology of parts combined to create a new upper-level reality with a distinct character that varies according to the proportions of the mixture. ${ }^{46}$ On one reading of the Nātya Śāstra, the aesthetic mode of perception 'generalises' the subsidiary parts of the drama and experiences of the protagonists in a 'melting away of the boundaries of personality' (Chakrabarti 2009, p. 191). ${ }^{47}$ This implies that an 'impersonal subjectivity' is generated in art experiences, expanding our affective response beyond immediate concerns so that it is able to roam across our 'modal awareness' (Boruah 2016, p. 127).

On this account, ethically motivating affects (a) are plural in type, so that in addition to suffering or happiness, other emotions like passion, heroic energy, or disgust, also 
motivate us; (b) exist in combinations that generate new overarching states (moods or attitudes)—indeed, some of the most prominent forms of suffering in drama are suffering for love or for justice; (c) are scalable to both personal responses and generalised 'ownerless emotions' (Chakrabarti 2009) that extend beyond the ego to respond to a wider situation. On this reading, what is of ethical value is the different possible trajectories of fulfilment of different constellations of desiderative feelings. It is neither merely personal, nor universal, but arises from the conditions of each particular province. ${ }^{48}$ It reconfigures the trolley-problem approach to ethical decisions as a plethora of switches not only for different possible actions and outcomes, but also addressing the different possible conjunctions of feeling and preference across persons.

It is helpful to compare this with a much-discussed Buddhist argument for altruism proposed by the c.8th century Madhyamaka Buddhist philosopher Sāntideva. Buddhism takes $d u k k h a$ or suffering as something that is self-evidently and universally agreed to be undesirable, possessing an innately aversive nature - this is to say that it is intrinsically ethical in the sense that it is innately motivational: anyone who understands it naturally sees that it would be better for it not to exist. As Śāntideva puts it, pains 'must be warded off simply because they are suffering ... If one asks why suffering should be prevented, no one disputes that!' (Bodhicaryāvatara, cited in (Williams 1998, p. 106)). ${ }^{49}$

This view makes at least three assumptions: firstly, it takes suffering as something that intrinsically motivates aversion-despite the fact that we often choose suffering as integral to some wider good, or find suffering to be inextricably combined with a good like strength, or development, or realisation. The famous 18th century Bengali poet Ramprasad Sen wrote 'Does suffering scare me?... O Mother, Let me suffer in this world. Do I require more?... I thrive on poison!' (Ramprasad Sen (1982) translated in Nathan and Seeley). As we have seen, the idea that humans can distance themselves from the causality of their immediate pain and pleasure to attend to other factors is a common theme in classical Hindu culture (and we have not even spoken of the yogic tradition with its practices of impulse control). Secondly, the Buddhist account pays little attention to other emotions that may have a motivational character-such as desire, affection, or disgust, to name a few of the canonical Indian aesthetic emotions. Thirdly, Sāntideva's account sees the natural state of the ego as concerned with its own desire and suffering, and only treats altruism as flowing from elimination of the ego; the kind of advice that Sulabhā gives the king, that his ego includes others, is foreign to this view. Each of these assumptions contrasts with the more complex model of emotions found in classical aesthetic theory.

However, in this case, it is not necessary to deny the ontological legitimacy of the self in order to secure a basis for altruism, as the Buddhist argument does. Instead it flows directly from the self's capacity for generalised feeling, which art so vividly exercises. Specific cases of vigour can become a generalised 'heroic' attitude that is ready to strive with circumstance; sorrow for one's own suffering is transformed into a wider desire that suffering should cease; desires become a sensitivity to attractions of all kinds and desirous that they should be savoured in general. In dramaturgy, it is the generalised emotion and the desire it entails for a certain situational outcome that creates dramatic tension; we 'feel' what outcome would best fit the combined value of the situation and hope that such a state of affairs will come to pass. Transposed to ethics, this creates a sense of what is of value/disvalue for the specific situation, and what state of affairs we would direct our agency toward. Indeed, while there is not scope to develop this idea here, rasa theory might be seen to perform the curious trick of describing how situations generate their own emergent axiology of value from relevant affects and motives.

There were subsequent debates about whether rasa could prompt ethical action (for key thinkers like the aesthetic theorist, philosopher and theologian Abhinavagupta, it creates only alaukika or otherworldly emotions associated with the spectating of fictional worlds), but the Nātya Śāstra itself emphasises that narrative art does indeed perform an ethical purpose. ${ }^{50} \mathrm{~A}$ frame narrative claims that drama teaches us how to do well whatever is our goal, regardless of the trajectory or province of life we are caught up in. It positions 
the arts as distractions to liberate the masses (including lower classes) from their grāmyadharma, a term used to mean the rustic pleasures of village life (1.8). Drama holds up a mirror to life and helps us to navigate it better:

... duty to those offending duty, desire to those devoted to it, accomplishment to those who are ill-bred, self-restraint in those who are undisciplined, virility to the weak, strength to heroes, enlightenment to the unintelligent, and learning to the wise ... this drama created by me is an imitation of the world's action, endowed with varied emotions and presenting different situations, the conjunction of the acts of highest, lowest and middling men, giving advice that leads to fortitude, amusement, happiness and the rest. ${ }^{51}$

This framing device for the whole field of drama in the Nātya Śāstra emphasizes that it is meant to augment the human world in each of its goals, and in explicit acknowledgement of the way that action interweaves with situation-embedded emotional values pertaining to multiple agents and outcomes. In so far as it offers ethical advice, the goal is not to tell people what to do but to instruct them in each their own province whilst keeping an eye on the whole, as we have seen throughout these classical sources. The technique of expanding aesthetic response, so that it generates overarching values that can be applied beyond the immediate situation, resonates with a wider idea that stories cultivate emotional sophistication-from the Mahäbhārata's origin story that it arose from the poetic expression of a sage's compassion toward a bird that had lost its mate, to the eleventh century aesthetic theorist King Bhoja's idea that "it is the purpose of literature-through the sense of the literary work as a whole" (the mahāvākyaikārtha) that provides specific insight into what one should and should not do (vidhiniședhapratibhāviśeșa) - to help us develop a comprehensive moral imagination" (Pollock 1998, p. 141). Mere emotions happen when we are thrown into situations; ethical emotions arise out of our ability to gain an overview of situations, and to empathise, synthesise, and abstract our emotional consciousness.

\section{The Ontology of Value in Indian Philosophy}

In the views we have considered so far, dharma's scalable order of cause-and-effect, the self's shapeable agency, and the different magnitudes of emotional value are all conditioned by a distinctive ontology that underpins their malleability. Dharma describes the principle of individual participation in the universal field of causal connections that, in their different local functions, sustain the upper-level features of our world-including biological life, society, and so on. In this sense, here dharma is precisely the kind of ethics that fits a thoroughly 'bottom-up' metaphysics, rather than a 'top-down' deontology. Each agent is a nexus in that landscape, and the Caraka Saṃhitā and story of Sulabhā remind us that we ourselves are complex, variable systems within a wider fabric of the same-but the emergent faculty of reason allows us to selects the parameters of our attention and agency. Uninformed, unreflective agency merely accedes to the most local natural causes flowing through it; this disposition is what we generally call 'egoism', but high-functioning ethical agency has a wider rational grasp of the context and uses agency with awareness of its scalable and curatable character. There can never be just one right thing to do because there is never one thing that we do; the meaning of actions depend on the province according to which we interpret them. Ethical agents, motives, decisions, actions, and consequences are not discrete but rather are 'vectors' as Sen (1980) put it in his account of the multiple variables of 'plural utility'. The variables must be filled in before we can see what is best. Even value-here understood as anchored in the raw ingredient of qualitative affective states-emerges from the bottom up, built from the conjunction of situations, personalities, relationships, desires, and the many possible outcomes that attend each act. A rasa-grounded ethics would say little about world-independent goodness, or values in a world without affective consciousness, for it grows out of the bedrock of the world itself.

As with many wider Indian approaches, here metaphysical understanding naturally feeds our agency and ethical disposition. In this sense, is and ought are not separate. For this reason, the act of ontological redefinition is also a process of phenomenological 
transformation: metaphysical comprehension is an ethical act. By contrast to Buddhist schools that typically put the elimination of suffering at the heart of their ethics (and also make it a motivation for soteriology, as do many Hindu sources), the perspectives in these texts take a slightly different approach. They think in terms of sustaining the infrastructure of life, engaging knowingly in the practices of preference and choice, and cultivating evaluative attitudes aimed beyond the ego's immediate desires.

Context is everything; understood as lovers in a private romance, Romeo and Juliet (or Devdas and Parvati) should follow their impulses and seek passion's fulfilment; however, understood as players in a political morality play, it might be best that their thwarted love inspires the community to future self-reflection. Understood as a tragedy, perhaps the play really is best at its most unmitigatedly dark: that too has its 'value'. Ethical evaluation and action is always tied up with a choice of self and scope of concern. We see this in the Bhagavad Gìtā's injunction to act for the world, the Âyurvedic doctor's analysis of wellbeing in terms of disposition and context, Sulabhā's advice that the sovereign act for his realm, and the Nātya Śāstra's 'cookbook' for using different story configurations to generate different emotions toward the whole story and across the whole audience. Hinduism tends to emphasise the wide scope of the multi-protagonist, multi-system, causally complex, and continually self-shaping world, rather than the narrow scope of do-we/do-we-not 'trolley problems.' The push against pure egoism flows not from the non-existence of selves but from the capacity of selves to scale-up and think, 'feel', and act more widely so that attention to the most narrowly local hedonic desires has no greater priority than attention to community, kingdom, or environment.

As a last point, it is worth noting that this approach draws no line between sacred and secular. Moral guidance is ultimately meant not to accord with divine standards, nor primarily to grow virtues for which we will be rewarded. Its main goal is to help the discriminating agent guide him or herself in the field of worldly possibilities. This tells us something about Hinduism qua 'religion': there is a humanistic character to much Hindu ethics, even when it acknowledges a soteriology that transcends this worldly concern. The Bhagavad Gitta uses the metaphor of a 'field' for the realm of dharma on which we live as world-embedded agents, suggesting that we see the field of moral action as a topographical phenomenon. Ethics is a landscape of many different provinces outlined beside and within each other: different needs obtain in different places-at urban centres, in the countryside, or at the borders. The sphere of morality manifests precisely when we widen our view over the landscape in order to recognise the consequences of our action for the wider ecology of the world. Given this, perhaps it is also significant that these texts use analogies of creativity. Like a godly Creator, a king, a doctor, a playwright, or a cook, we all create the world daily - we use the dynamic bricolage of each situation moment by moment to craft our own dispositions and desires, our world's systems and its future, and the overall affective experiences that take place in it.

Funding: This research received no external funding.

Institutional Review Board Statement: Not applicable.

Informed Consent Statement: Not applicable.

Data Availability Statement: Not applicable.

Conflicts of Interest: The author declares no conflict of interest.

\section{Notes}

Lokasaṃraham evāpi sampaśyan kartum arhasi | I Bhagavad Gītā 3.20.

Vimṛ́yaitad aśeṣeṇa yathecchasi tathā kuru | I Bhagavad Gìtā 18.63.

The main texts in this paper are connected only loosely by the exegetically continuous, Sanskritic, largely Brahminical culture of the communities who composed them; in the case of the Mahäbhärata alone, multiple sources are redacted into a duty-andrenunciation themed collection with its own internal tensions (see (Fitzgerald 2001, p. 63) on its 'bi-polar' approach to ethics, and (Malinar 2007, pp. 28-29) on the history of interpreting it as a meeting of householder and renouncer ideologies, e.g., Louis 
Dumont, Madeleine Biardeau, and van Buitenen on the solution proposed in bhakti). The very sections of the Caraka Samhitā (Śarìrasthāna) and Nātya Śāstra (chapter six) that we explore may be interpolations into those texts (see below). Much of this classical corpus falls under the general thesis of a Brahminical editorship that was hermeneutically unified by 'adaptive reuse' of reference points that include the Upanișads and a contemporary community of Sāmkhya teachers. Indeed, there is a growing discourse on the implications of redaction, reuse, and allusive reasoning for Indian literature generally (Freschi and Maas 2017), more work is needed on the way this affects methods of philosophical reasoning in India (see (Freschi 2015) on textual-historical issues).

4 There is an extensive literature on Jain perspectivalism, context-dependence (Balcerowicz 2015, p. 225), relativity of truth (Long 2018), strategic 'adaptability' to context (Qvarnström 1998), 'multiplism' (Ram-Prasad 2007), and its use of these views to construct a 'dialogical identity' (Barbato 2019).

5 (Matilal 2002, p. 37); See also the essays "Elusiveness and Ambiguity in Dharma-Ethics" and "Dharma and Rationality" in the same volume.

6 By emergence, in this paper we mean any account of constitution in which constituents configured in a certain way generate a phenomenon marked out as new by (a) new properties, (b) new causal powers, and in many cases (c) top-down causation over those very constituents.

7 The Sāmkhya school is generally seen as a dualist school, but as Burley has noted, the Western mind-matter divide misrepresents its metaphysics, and early versions seem to have been concerned primarily with the way that the world is made of combinations or evolutes of underlying material elements (on early or 'proto-sāṃkhya', see (Larson 1979; Jacobsen 1999; Johnston 1937)).

8 Like the teaching ascribed to Pañcaśikha in Sulabhā's discourse, it may be that Pañcaśikha's own teaching in Mahābhārata 211-212 also gives a emergent account of the individual self as arising from and mixed up in the body's elements (see Malinar 2017a, 637-638) so that 'Perception is possible when the ten sense faculties, manas and buddhi perform simultaneously their respective functions.'

9 Scholarship (see (Malinar 2007, pp. 29-34) for a balanced synthesis of competing text-historical perspectives) situates the Bhagavad Gìtā in historical context as an internally complex addition to the longue durée development of the Mahābhārata, a process that incorporated subsidiary redaction of sources into a single tightly woven teaching similar to other Vedānta- and Sāmkhyainfluenced, counter-Buddhist discourses in sections such as the Anugītā and Mokșadharma. It is distinctive in harnessing both ascetic and ritual religious styles into a curious combination that allows for a new commitment to social responsibility, shored up within a new 'cosmological monotheism'; see (Malinar 2007, p. 237; Van Buitenen 2013; Upadhyaya 1971).

10 The presence of reincarnation in the Hindu cosmology impacts ethical thought in that there is no way to opt out of ethical action; suicide would simply bring new life and further experience. Inaction is denied as a philosophically significant category here because it is as much part of the causal fabric of things as willing action is-a fact brought home to the tradition by the Bhagavad Gìtā's central example of a general who jeopardises the people by refusing to lead his army in battle.

11 This form of thinking about action may derive from the rationale articulated for ritual activity by the Mīmāmsā school at a very early stage of Vedic society: rituals both advanced the innate good of ritual activity itself, and also secured specific rewards so that the form of action related directed to desired outcome, yet at the same time 'the motivation of the ritual is thus intimately connected to its overall organization and the big picture of what one is trying to do' (Davis 2010, p. 50). See (Freschi 2007) on the construction of agency in Mīmāṃsā, and Freschi et al. (2018), for a survey of philosophical insights in the Mīmāmsā approach to ethics.

12 See Mānava Dharma Śāstra chapter one.

13 ... tena teșām lokah | yathā ha vai svāya lokāyāriștim icchet evam haivam vide sarvāṇi bhūtāny ariṣtim icchanti | | Bṛ̂had Äranyaka Upaniṣad 1.4.16.

14 Malinar (2007, p. 5) argues that lokasamgraha arises in the Bhagavad Gìtā as a novel application of yogic 'ascetic practices' of self-control and self-restraint to the ritual and social responsibility of dharma.

15 Evam pravartitạ̣ cakram nānuvartayatīha yạ̣ I aghāyur indriyārāmo moghạ̣ Pārtha sa jīvati | I ... tasmād asaktaḥ satatam kāryạ̣ karma samācara I asakto hy ācaran karma param āpnoti pūruṣạ̣ | | karmaṇaiva hi saṃsiddhim āsthitā janakādayaḥ | lokasạ̣graham evāpi sampaśyan kartum arhasi I I Bhagavad Gītā 3.16, 19-20.

16 Yadi hy ahạ̣ na varteyạ̣ jātu karmaṇy atandritạ̣ | mama vartmānuvartante manuṣāḥ Parthā sarvaśaḥ | | utsīdeyur ime lokā na kuryāṃ karma ced aham I saṃkarasya ca kartā syām upahanyām imāḥ prajāḥ̣ | | Bhagavad Gìtā 3.23-24.

17 Lesser reflections of this 'I know and perform my role for the world' principle are found throughout the Mahābhārata (as for instance in the case of the low-caste hunter who argues for the virtue of his own impure and violent trade; 3.198-199). Yet the text is famously ambiguous about exactly how embedded we should be in our social roles and moral customs, and it often depicts the evident inequity of applying these rules as a social system regardless of individual skills (as in the tale of the skilled but low-caste marksman Eklavya) or explicitly criticises the excessively strict following of social rules without assessing their larger implications, as in the complaints of Draupadī about her too-courteous husband in the 'dicing' episode, Krishna's explanation that it can be good to lie sometimes in the tale of Kauśika and the bandits (see the discussion in (Lipner 2019), and studies on the epic's more subversive tales in (Brodbeck and Black 2007)), and Sulabhā's critique of expectations about an unmarried woman's place in public. 
On the history of Āyurveda and its notions of the self, see (Cerulli 2012; Wujastyk 2012b; Robertson 2017). The Caraka Samhitā itself is a composite work dating from approximately the same centuries c. 300 BCE to 200 CE as the Mahābhārata, and while it incorporates various versions of the broadly proto-Sāmkhya, and sometimes Vedāntacised ideas we see elsewhere in the Upanișads and Epics, it also directly cites the 2nd BCE atomist Vaiśeșika Sūtra, and passages from Buddhist literature. Hitāhitam sukham duhkham āyus | I Caraka Saṃhitā, Sūtrasthāna 1.41

20 Dharmārthakāmamokṣānāam ārogyaṃ mūlam uttamam | | rogās tasyāpahartāraḥ śreyaso jīvitasya ca | Caraka Saṃhitā, Sūtrasthāna $1.15-16$.

21 Atra karma phalam cātra jñānam cātra pratiṣtitam I atra mohạ̣ sukhạ̣ dụ̣kham jīitam maraṇạ̣ svatā | | evam yo veda tattvena sa veda pralayodayau I pāraṃparyam cikitsāṃ ca jñātavyạ̣ yac ca kị̣ cana I I bhās tamaḥ satyam anṛtaṃ vedāḥ karma śubhāśubham I na syụ̣ kartā ca boddhā ca puruṣo na bhaved yadi I I nāśrayo na sukham nārtir na gatir nāgatir na vāk | na vijñānaṃ na śāstrāni na janma maraṇaṃ na ca I I na bandho na ca mokṣaḥ syāt puruṣo na bhaved yadi I kāraṇam puruṣas tasmāt kāraṇajñair udāhṛtaḥ | I (Caraka Saṃhitāe Śarīrasthāna 1.37-41).

Āsāṃ tu khalv eṣaṇānāṃ prāṇaiṣaṇām tāvat pūrvataram āpadyeta I kasmāt prāṇaparityāge hi sarvatyāgah | Caraka Saṃhitā, Sūtrasthāna 11.4. Jñānaṃ jñeyaṃ parijñātā trividhā karmacodanā I karaṇaṃ karma karteti trividhaḥ karmasamgrahah; Bhagavad Gītā 18.18. Sattvam ātmā śarīraṃ ca trayam etat tridaṇdavat Caraka Saṃhitā, Sūtrasthāna 1.46.

Śarīrendriyasattvātmasaṃyogo; Caraka Saṃhitā, Sūtrasthāna 1.42. Here the text describes a classic Vaiśeșika model of actions and properties (karma, guna) rooted in substances (dravya; see 1.51). What is valued most is that which is balanced (samah).

Disorders of constitutional imbalance can be treated through the application of knowledge, understanding, fortitude, memory and concentration: mānaso jñānavijñānadhairyasmṛtisamādhibhiḥ; Caraka Saṃhitā, Sūtrasthāna 1.58. The state of the mind and body should also be adjusted according to the seasons to achieve an optimal harmony with the environment.

This passage includes dualistic Sāmkhya ideas of the essential puruṣa as separate from the embodied personality, but focuses on the latter.

The discussion in the Caraka Samhitā concerns the 'locus' of the self (often āśraya), and seems to address it in the sense that Jonardon Ganeri discusses as 'place,' distinguishing both Indian 'tornado' views of self as a formation produced by a force creating a pattern of dynamic flow, and 'flame' views identifying self as a state emerging from the mutual causal interaction of subsidiary constituents (Ganeri 2011, pp. 43-46), as well as the 'no place' view of the Abhidharma Buddhists. On emergence as a theory of self in India see (Ganeri 2011), where he also discusses the possibility of a wholly supervenient relationship of constitution, and Ram-Prasad (2018, pp. 27-54) on the 'ecological' view of the self in the Caraka Saṃhitā.

Na kartur indriyābhāvāt kāryajñānaṃ pravartate | yā kriyā vartate bhāvaiḥ sā vinā tair na vartate | I jānann api mṛdo ‘bhāvāt kumbakṛn na pravartate I Caraka Saṃhitā, Śarīrasthāna 3.19.

30 Sarvalokam ātmany ātmānam ca sarvaloke saman upaśyatạ satyā buddhị samutpadyate I sarvalokaṃ hy ātmani paśyato bhavaty ātmaiva sukhadụ̣khayoḥ kartā nānya. Caraka Saṃhitā, Śarīrasthāna 5.7.

31 This tale is discussed by (Fitzgerald 2003; Sutton 2000; Smith 2007; Dhand 2009; White 2009; Badrinath 2008; Vanita 2003).

32 There are some similarities between this view of the self and that of Buddhism, and so too, connections have been noted between passages in the Caraka Saṃhitā and Buddhist texts like the Abhidharmakośabhāṣya (see Bronkhorst 2002), the Buddhist affirmation of medical care (Zysk 1992), the Buddhist idea of an eightfold path (see Wujastyk 2012a), and the Buddhist view in which 'process is privileged over substance' (Wujastyk 2009, p. 19). Here we agree with the view that this does not 'have any explicit indication of being a Buddhist teaching' (Fitzgerald 2003, p. 642) and instead reflects the dialectic of a fruitful integration of Buddhist ideas in 'a milieu in which a body of systematic technical medical knowledge existed' yielding a 'profoundly syncretic text' (Wujastyk 2012a, pp. 32, 36); such as we find throughout Hindu (and indeed, Indian) thought), rather than a cryptobuddhist variation from the Hindu orthodoxy. Given the permeation of Buddhist and Hindu thought, and the complexity of both traditions, it seems that enforcing a strict categorisation of 'Hindu' and 'Buddhist' may be artificial.

33 The ethical import of her analysis of selfhood fits well in its literary context; the Śāntiparvan's section on Mokṣa or liberation, of which 12.308 is a part, sits alongside sections on statecraft and social ethics (the Rājadharma and āpaddharma

34 Mahābhārata 12.308.103-109.

35 Pratibhedah kṣaṇe kṣaṇe. Mahābhārata 12.308.121-122. "The birth and death of particles in each successive condition cannot be marked, $\mathrm{O}$ king, even as one cannot mark the changes in the flame of a burning lamp. (kalānāṃ pṛthag arthānām pratibhedaḥ kṣaṇe kṣaṇe I vartate sarvabhūteșu saukṣmyāt tu na vibhāvyate I I na caiṣām apyayo rājam lakṣyate prabhavo na ca l avasthāyām avasthāyạ̣ dīpasyevārciṣo gatị̣ | I).

36 Saṃbandhaḥ ko ‘sti bhūtānāṃ svair apy avayavair iha I I yathādityān maṇeś caiva vīrudbhyaś caiva pāvakaḥ | bhavety evaṃ samudayāt kalānām api jantavaḥ | I ātmany evātmanātmānạ̣ yathā tvam anupaśyasi l evam evātmanātmānam anyasmin kiṃ na paśyasi I I yady ātmani parasmiṃś ca samatām adhyavasyasi I I Mahāohārata 12.308.124-126.

Yathā jatu ca kāṣthạ̣ ca pāṃsavaś coda bindubhị̣ | suśliṣtāni tathā rājan prāninām iha saṃhavaḥ | I śabdah sparśo raso rūpaṃ gandhaḥ pañcendriyāṇi ca | pṛthag ātmā daśātmānạ̣ saṃśliṣtā jatu kāṣthavat | I na caiṣāṃ codanā kā cid astīty eṣa 
viniścayaḥ | ekaikasyeha vijñānaṃ nāsty ātmani tathā pare | | . . bāhyān anyān apekṣante gunāṃs tān api me śṛ̣u | rūpam cakṣuh prakāśaś ca darśane hetavas trayaḥ I I yathaivātra tathānyeșu jñānajñeyeșu hetavah. Mahābhārata 12.308.97-101.

\section{References}

\section{Primary Sources}

(Bhagavad Gìtā) The Bhagavad Gìtā: Twenty-fifth Anniversary Edition. 2009. Translated by Winthrop Sargeant. Edited by Christopher Key Chapple. Albany: State University of New York Press.

(Caraka Saṃhitā) Caraka Saṃhitā: Text with English Translation. 2005. Translated by P.V. Sharm. Varanasi: Chaukambha Orientalia.

(Mānava Dharma Śāstra) Manu's Code of Law: A Critical Edition and Translation of the Mānava Dharma Śāstra. 2004. Edited and Translated by Patrick Olivelle. New York: Oxford University Press. 
(Nātya Śāstra) Nātya Śāstra: Sanskrit Text with Transliteration and English Translation, Vols. I-II. 2016. Edited and Translated by Manmohan Ghosh. Varanasi: Chaukhamba Surbharati Prakashan.

\section{Secondary Sources}

Anderson, Joshua. 2012. Sen and the Bhagavad Gita: Lessons for a Theory of Justice. Asian Philosophy 22: 63-74. [CrossRef]

Badrinath, Chaturvedi. 2008. Women of the Mahabharata: The Question of Truth. Hyderabad: Orient Blackswan.

Balcerowicz, Piotr. 2015. Do attempts to formalize the Syād-vāda make sense? In Jaina Scriptures and Philosophy. Edited by Peter Flügel and Olle Qvarnström. London: Routledge, pp. 181-248.

Barbato, Melanie. 2019. Anekāntavāda and Dialogic Identity Construction. Religions 10: 642. [CrossRef]

Bhattacharya, Ramkrishna. 2017. History of Materialism from Ajita to Udbhata'. In The Oxford Handbook of Indian Philosophy. Edited by Jonardon Ganeri. Oxford: Oxford University Press. [CrossRef]

Bilimoria, Purushottama. 1995. Ethics of Emotion: Some Indian Reflections. In Emotions in Asian Thought: A Dialogue in Comparative Philosophy. Edited by Joel Marks, Robert Solomon and Roger Ames. Albany: State University of New York, pp. 65-84.

Boruah, Bijoy. 2016. The Impersonal Subjectivity of Aesthetic Emotion. In The Bloomsbury Handbook of Indian Aesthetics and the Philosophy of Art. Edited by Arindam Chakrabarti. London: Bloomsbury, pp. 127-48.

Brodbeck, Simon. 2004. Calling Krishna's Bluff: Non-Attached Action in the Bhagavadgītā. Journal of Indian Philosophy 32: 81-103. [CrossRef]

Brodbeck, Simon, and Brian Black. 2007. Gender and Narrative in the Mahābhārata. Abingdon: Routledge.

Bronkhorst, Johannes. 2002. A Note on the Caraka Saṃhitā and Buddhism. In Buddhism and Abhidharma thought: In Honor of Doctor Hajime Sakurabe on His Seventy-Seventh Birthday. Kyoto: Heirakuji Shoten, pp. 115-21.

Cerulli, Anthony. 2012. Somatic Lessons: Narrating Patienthood and Illness in Indian Medical Literature. Albany: SUNY.

Chakrabarti, Arindam. 2009. Play, Pleasure, Pain: Ownerless Emotions in Rasa Aesthetics. In Project of History in Indian Science, Philosophy, and Culture. Edited by Amiya Dev. New Delhi: Centre for Studies in Civilisations, vol. 15, pp. $189-202$.

Chakrabarti, Arindam. 2016. The Bloomsbury Handbook of Indian Aesthetics and the Philosophy of Art. London: Bloomsbury.

Chatterjee, M. 1986. Facts and Values: Philosophical Reflections from Western and Non-Western Perspectives. Edited by Marinus Doeser and John Kraay. Boston: Martinus Nijhoff, pp. 177-87.

Clooney, Francis. 2018. Toward a Complete and Integral Mīmāṃsā Ethics: Learning with Mādhava's Garland of Jaimini's Reasons. In The Bloomsbury Research Handbook of Indian Ethics. London: Bloomsbury, pp. 229-318.

Comba, Antonella. 2011. Caraka Saṃhitā, Śārīrasthāna I, and Vaiśeșika Philosophy. In Studies on Indian Medical History. Edited by Jan Meulenbeld and Dominik Wujastyk. Delhi: Motilal Banarsidass, pp. 1-16.

Coseru, Christian. 2016. Consciousness and Causal Emergence: Sāntarakṣita against Physicalism'. In The Oxford Handbook of Indian Philosophy. Edited by Jonardon Ganeri. Oxford: Oxford University Press. [CrossRef]

Davis, Donald. 2010. The Spirit of Hindu Law. Cambridge: Cambridge University Press.

De, Sushil Kumar. 1976. History of Sanskrit Poetics. Calcutta: Firma KLM.

Dhand, Arti. 2009. Paradigms of the Good in the Mahābhārata: Suka and Sulabhā in quagmires of Ethics. In Gender and Narrative in the Mahābhārata. Edited by Simon Brodbeck and Brian Black. Abingdon: Routledge, pp. 258-78.

Doniger, Wendy. 1973. Asceticism and Eroticism in the Mythology of Siva. Oxford: Oxford University Press.

Eliade, Mircea. 2009. Yoga: Immortality and Freedom. Princeton: Princeton University Press.

Fitzgerald, James. 2001. Making Yudhișthira the King: The Dialectics and the Politics of Violence in the Mahābhārata. Rocznik Orientalistyczny 54: 63-92.

Fitzgerald, James. 2003. Nun Befuddles King, Shows Karmayoga Does not Work: Sulabhā's refutation of King Janaka at MBh 12.308. Journal of Indian Philosophy 30: 641-77. [CrossRef]

Fitzgerald, James. 2015. "Saving Buddhis" in Epic Mokṣadharma. International Journal of Hindu Studies 19: 97-137. [CrossRef]

Frazier, Jessica. 2017. Hindu Worldviews: Theories of Self, Ritual, and Reality. London: Bloomsbury.

Freschi, Elisa. 2007. 'Desidero Ergo Sum: The Subject as the Desirous One in Mīmāṃsā'. Rivista Degli Studi Orientali 80: 51-61.

Freschi, Elisa. 2015. The Reuse of Texts in Indian Philosophy. Journal of Indian Philosophy 43: 85-108. [CrossRef]

Freschi, Elisa, and Phillip Maas. 2017. Adaptive Reuse: Aspects of Creativity in South Asian Cultural History. Wiesbaden: Harrassowitz.

Freschi, Elisa, Andrew Ollett, and Matteo Pascucci. 2018. Duty and Sacrifice: A Logical Analysis of the Mīmāmsā Theory of Vedic Injunctions. History and Philosophy of Logic 40: 323-54. [CrossRef]

Ganeri, Jonardon. 2005. A Dynamic Tradition of Truth-Telling: Moral Innovation in the Mahabharata. In Boundary Dynamics and Construction of Traditions in South Asia. Edited by Federico Squarcini. Florence: University of Florence Press and Munshiram Manoharlal, pp. 175-201.

Ganeri, Jonardon. 2011. Emergentisms, Ancient and Modern. Mind 120: 671-703. [CrossRef]

Ganeri, Jonardon. 2017. Attention, Not Self. Oxford: Oxford University Press.

Garfield, Jay. 2015. Engaging Buddhism: Why It Matters. Oxford: Oxford University Press.

Gaucchwal, Balbir Singh. 1958. A Comparative Study of the Ethical Teachings of Kant and the Bhagavad Gìtā. Delhi: Motilal Banarsidass.

Gibbard, Allan. 1992. Thick Concepts and Warrant for Feeling. Proceedings of the Aristotelian Society 66: 267-83. [CrossRef]

Gupta, Bina. 2006. The Bhagavad Gītā as Duty and Virtue Ethics. Journal of Religious Ethics 34: 373-95. [CrossRef] 
Hayashi, Itsuki. 2016. Persons as Weakly Emergent: An Alternative Reading of Vasubandhu's Ontology of Persons. Philosophy East and West 66: 1218-30. [CrossRef]

Hegarty, James. 2019. Models of Royal Piety in the Mahābhārata: The Case of Vidura, Sanatsujāta and Vidurā. In Dialogue with Classical Indian Traditions: Encounter, Transformation and Interpretation. Edited by Brian Black and Chakravarthi Ram-Prasad. Abingdon: Routledge, pp. 211-27.

Heim, Maria. 2005. Differentiations in Hindu Ethics. In The Blackwell Companion to Religious Ethics. Edited by William Schweiker. Oxford: Blackwell Publishing, pp. 341-54.

Jacobsen, Knut Axel. 1999. Prakrti in Sāṃkhya-Yoga: Material Principle, Religious Experience, Ethical Implications. New York: Peter Lang.

Johnston, E. H. 1937. Early Samkhya: An Essay on its Historical Development according to the Texts. London: Royal Asiatic Society.

Larson, Gerald James. 1979. Classical Sāmkhya: An Interpretation of its History and Meaning. Delhi: Motilal Banarsidass.

Lipner, Julius. 2019. The Truth of Dharma and the Dharma of Truth: Reflections on Hinduism as a Dharmic Faith. International Journal of Hindu Studies 23: 213-23. [CrossRef]

Long, Jeffrey. 2018. Consciousness and Relativity: Anekāntavāda and its Role in Jaina Epistemology. South Asian History and Culture 9: 280-95. [CrossRef]

Mahony, William. 1998. The Artful Universe: An Introduction to the Vedic Religious Imagination. Albany: State University of New York.

Malinar, Angelika. 2007. The Bhagavad Gītā: Doctrine and Contexts. Cambridge: Cambridge University Press.

Malinar, Angelika. 2017a. Narrating Sāṃkhya Philosophy: Bhīṣma, Janaka and Pañcaśikha at Mahābhārata 12.211—12. Journal of Indian Philosophy 45: 609-49. [CrossRef]

Malinar, Angelika. 2017b. Philosophy in the Mahābhārata and the History of Indian Philosophy. Journal of Indian Philosophy 45: 587-607. [CrossRef]

Masson, J. L., and M. V. Patwardhan. 1970. Aesthetic Rapture, the Rasādhyāya of the Nāțaásāstra. Poona: Deccan College Postgraduate and Research Institute.

Matilal, Bimal Krishna. 2002. Moral Dilemmas and Religious Dogmas. In The Collected Essays of Bimal Krishna Matilal: Ethics and Epics. Edited by Jonardon Ganeri. New Delhi: Oxford University Press, pp. 3-13.

Moise, Ionut. 2019. Salvation in Indian Philosophy: Perfection and Simplicity for Vaiśeșika. Abingdon: Routledge.

Monius, Anne. 2005. Origins of Hindu Ethics. In The Blackwell Companion to Religious Ethics. Edited by William Schweiker. Oxford: Blackwell Publishing, pp. 330-40.

Moore, George Edward. 1959. Principia Ethica. Cambridge: Cambridge University Press.

Olivelle, Patrick. 2004. Manu's Code of Law: A Critical Edition and Translation of the Mānava Dharmaśāstra. New York: Oxford University Press.

Perrett, Roy. 2005. Hindu Ethics? In The Blackwell Companion to Religious Ethics. Edited by William Schweiker. Oxford: Blackwell Publishing, pp. 323-29.

Pollock, Sheldon. 1998. Bhoja's Śrñgāra Prakāśa and the Problem of Rasa: A Historical Introduction and Annotated Translation. In Asiatische Studien. Bern: Peter Lang, pp. 117-92.

Pollock, Sheldon. 2010. What was Bhața Nāyaka saying? The Hermeneutic Transformation of Indian Aesthetics. In Epic and Argument in Sanskrit Literary History: Essays in Honor of Robert P. Goldman. Delhi: Manohar, pp. 143-84.

Pollock, Sheldon. 2016. The Rasa Reader: Classical Indian Aesthetics. New York: Columbia University Press.

Potter, Karl. 1991. Presuppositions of Indian Philosophies. Delhi: Motilal Banarsidass.

Prasad, Rajendra. 2008. A Conceptual-Analytic Study of Classical Indian Philosophy of Morals. New Delhi: Centre for Studies in Civilisations.

Proferes, Ted. 2007. Vedic Ideals of Sovereignty and the Poetics of Power. New Haven: American Oriental Society.

Qvarnström, Olle. 1998. Stability and Adaptability: A Jain Strategy for Survival and Growth. Indo-Iranian Journal 41: 33-55. [CrossRef]

Ramanujan, Adhipate Krishnaswami. 1989. Is There an Indian Way of Thinking? An Informal Essay. Contributions to Indian Sociology 23: 41-58. [CrossRef]

Ram-Prasad, Chakravarthi. 2007. Indian Philosophy and the Consequences of Knowledge: Themes in Ethics, Metaphysics and Soteriology. Aldershot: Ashgate.

Ram-Prasad, Chakravarti. 2018. Human Being, Bodily Being: Phenomenology from Classical India. Oxford: Oxford University Press.

Robertson, Matthew. 2017. The Identity of Person and World in Caraka Saṃhitā 4.5. Journal of Indian Philosophy 45: 837-61. [CrossRef]

Scanlon, Tim. 2003. Thickness and Theory. Journal of Philosophy 100: 275-87. [CrossRef]

Sen, Amartya. 1980. Plural Utility. Proceedings of the Aristotelian Society 81: 193-215. [CrossRef]

Sen, Ramprasad. 1982. Grace and Mercy in her Hair: Selected Poems to the Mother Goddess by Rāmprasād Sen. Edited by Leonard Nathan and Clinton Seely. Bounder: Great Eastern Press.

Sen, Prabal Kumar. 2014. Moral Doubts, Moral Dilemmas and Situational Ethics in the Mahābhārata. In Mahābhārata Now: Narration, Aesthetics, Ethics. Edited by Arindam Chakrabarti and Sibaji Bandhyopadhyay. New Delhi: Routledge, pp. $153-202$.

Siderits, Mark. 2000. Reply to Paul Williams. Philosophy East West 50: 453-59.

Siderits, Mark. 2007. Buddhism as Philosophy: An Introduction. Indiana: Hackett Publishing Co.

Sinha, Shalini. 2016. The Metaphysics of Self in Praśastapāda's Differential Naturalism. In The Oxford Handbook of Indian Philosophy. Edited by Jonardon Ganeri. Oxford: Oxford University Press. [CrossRef] 
Smith, Frederick. 2007. The Self Possessed: Deity and Spirit Possession in the Literature and Civilisation of South East Asia. New York: Columbia University Press.

Sreekumar, Sandeep. 2012. An Analysis of Consequentialism and Deontology in the Normative Ethics of the Bhagavadgītā. Journal of Indian Philosophy 40: 277-315. [CrossRef]

Sutton, Nicholas. 2000. Religious Doctrines in the Mahābhärata. New Delhi: Motilal Banarsidass.

Upadhyaya, Kashi Nath. 1971. Early Buddhism and the Bhagavad Gītā. Delhi: Motilal Banarsidass.

Van Buitenen, Johannes Adriannes Bernardus. 2013. The Bhagavad Gītā in the Mahābhārata. Chicago: University of Chicago Press.

Vanita, Ruth. 2003. The Self is not Gendered: Sulabhā's Debate with King Janaka. NWSA Journal 15: 76-93. [CrossRef]

Vatsyayan, Kapila. 1995. The Nātyaśāstra. New Delhi: Sahitya Akademi.

White, David Gordon. 2009. Sinister Yogis. Chicago: Chicago University Press.

Williams, Paul. 1998. Altruism and Reality: Studies in the Philosophy of the Bodhicaryāvatāra. Richmond: Curzon.

Williams, Paul. 2000. Response to Mark Siderits' Review. Philosophy East and West 50: 424-53.

Wujastyk, Dominik. 2000. The Combinatorics of Tastes and Humours in Classical Indian Medicine and Mathematics. Journal of Indian Philosophy 28: 479-49. [CrossRef]

Wujastyk, Dominik. 2004. Medicine and Dharma. Journal of Indian Philosophy 32: 831-42. [CrossRef]

Wujastyk, Dominik. 2009. Interpreting the Image of the Human Body in Premodern India. International Journal of Hindu Studies 13: 189-228. [CrossRef]

Wujastyk, Dominik. 2012a. The Path to Liberation Through Yogic Mindfulness in Early Āyurveda. In Yoga in Practice. Edited by David Gordon White. Princeton: Princeton University Press, pp. 31-42.

Wujastyk, Dagmar. 2012b. Well-Mannered Medicine: Medical Ethics and Etiquette in Classical Āyurveda. Oxford: Oxford University Press. Zysk, Kenneth. 1992. Religious Medicine: The History and Evolution of Indian Medicine. New Brunswick: Transaction Publishers. 